\title{
A Perczel-glóbusz új interaktív névmutatója
}

\author{
UNGVÁRI Zsuzsanna-MÁRTON Mátyás
}

DOI: $10.30921 / G K .73 .2021 .3 .3$

Absztrakt: A 2007-ben Márton Mátyás által az Eötvös Loránd Tudományegyetem Térképtudományi és Geoinformatikai Tanszékén felvázolt Perczel-projekt eredményeképpen 2019-ben elkészült a 127,5 cm átmérôjü kéziratos földgömb teljes digitális restaurálása, majd rekonstrukciója. A tanszéken korábban, 2013-ig folyó - a földgömb megmentését célzó, számos oktató és hallgató munkáját felölelô - feladat végsố kartográfiai befejezése Márton Mátyásra, a projekt korábbi vezetôjére várt, aki ezt a munkát Paksi Judit közremüködésével végezte el. Ennek felhasználásával mód nyílt három müvészi hasonmásglóbusz elkészítésére is. Azt mondhatjuk, hogy ily módon újjászületett ez az egyedülálló, nagy kulturális értéket képviselö, ugyanakkor kartográfiai örökségünk szempontjából is igen jelentôs müalkotás, amely a 20. század megpróbáltatásai következtében helyrehozhatatlan sérüléseket szenvedett. A digitális rekonstrukciót követốn jó alkalom kínálkozott egy másik, korábbi, kapcsolódó projekt felelevenítésére, az Ungvári Zsuzsanna és Tokai Tibor munkájának eredményeképpen született „A Perczel-glóbusz interaktív névmutatója” címü honlap új, kibövített tartalmú létrehozására is. A tanulmány bemutatja a névmutató készítésének elözményeit, és ismerteti a jelenlegi feldolgozás legfontosabb lépéseit.

Abstract: As a result of the Perczel Project outlined by Mátyás Márton in 2007 at the Department of Cartography and Geoinformatics of Eötvös Loránd University (ELTE), the complete digital restoration and then reconstruction of the $127.5 \mathrm{~cm}$ diameter manuscript globe was completed in 2019. The final cartographic completion of the ongoing task at the department by 2013 - led by Mátyás Márton, the project manager, who carried out this work with the help of Judit Paksi -, which included the work of many lecturers and students, aimed at saving the globe. Using this augmented digital processing, it was also possible to create three artistic copies of Perczel's globe, which was originally made in 1862. This unique work of art, which has suffered irreparable damage due to the ordeals of the 20th century, is of great cultural value and also very important for our cartographic heritage, has been reborn. Following the digital reconstruction, there was a good opportunity to revive another related project. The website, "The interactive gazetteer of Perczel's globe", which was born as a result of the work of Zsuzsanna Ungvári and Tibor Tokai earlier, was also created with a new, expanded content. The present study presents the antecedents of gazetteer creation and describes the most important steps of current processing.

Kulcsszavak: virtuális glóbusz; földrajzinév-restaurálás, földrajzinév-rekonstrukció; nevek geoadatbázisa; interaktív névmutató Keywords: virtual globe; restoration and reconstruction of geographical names; name geodatabase; interactive gazetteer

\section{A névanyag restaurálása és rekonstrukciója a Perczel-projekt során}

A névanyag szempontjából megvizsgálva a Perczel-projektet, a feldolgozás két alapvetô lépésérôl beszélhetünk: a digitális restaurálás és a digitális rekonstrukció fázisairól.

A digitális restaurálás a névrajz esetében első lépésben azt jelentette, hogy a vastag, erôsen elsárgult-megbarnult „védő” lakkréteggel fedett, már a lakkozás elốtti idôszakban sok helyen erôsen megkopott eredeti glóbusztartalom kézzel megírt földrajzi neveit kibetûzzük, és az eredeti írásképnek megfelelően rögzítsük, figyelembe véve a betúszám alapján az írásmódot (ha legalább ennek megszámolására vagy a név hossza és a szórás alapján becslésére lehetôség adódik).

A restaurálás elsô fázisában tilos volt az olvashatatlan névelemek „kitalálása”, ezeket csak úgy egészíthettük ki, ha egykorú forrástérképek igazolták elképzelésünket. Mivel azonban nagy hallgatói energiát kötött le már csak a rosszul látható földrajzi nevek kibetûzése is, szinte minden névbe került(ek) kérdójel(ek) azon betûk helyére, amelyek olvashatatlanok voltak. Nem volt ritka az sem, hogy a teljes név helyén kérdójelek sorakoztak (1. ábra).

Az újrafeldolgozás során a névrajzhoz Perczel kézírásához közelálló betúformát adó modern fontokat használtunk. Ily módon elôállt egy névrajzi tartalmi hasonmás, ami színvilágát (Perczel színes névírást alkalmazott a földgömbön) és betûrajzi megjelenítését tekintve is hasonlít az eredeti glóbusz AmbrusFallenbüchl-féle leírása (1963) nyomán finomítható névrajzi képhez, azonban az eróteljesebb kopások okozta olvashatatlan térképelemek hiányoztak, vagy csak részben szerepeltek. A digitális restaurálás jelentôs hányada már 2012-ig elkészült.

A glóbusz múvészi hasonmásainak elkészítését közvetlenül megelôzô 2019-es restaurálási munkák során (Márton 2019) a korábban végzett kartográfiai újraalkotási folyamat eredményeinek (térképrajz, árnyékolt domborzatrajz és földrajzinév-anyag) ellenôrzése, a feltárt hibák javítása volt a feladat. A továbblépést a névrestaurálás szempontjából a korábban csak részben feltárt (egy vagy több kérdôjelet tartalmazó) nevek helyreállítása, korabeli térképek alapján történô kiegészítése, azaz a helyes névalak meghatározása jelentette.

Az előzô munkák folyamán teljesen feltáratlan nevek pótlása a névrajzi rekonstrukció. Ilyen nevek is nagy számban fordulnak elố a glóbusz fizikailag meg nem semmisült, de igen erôsen megkopott területein. A 


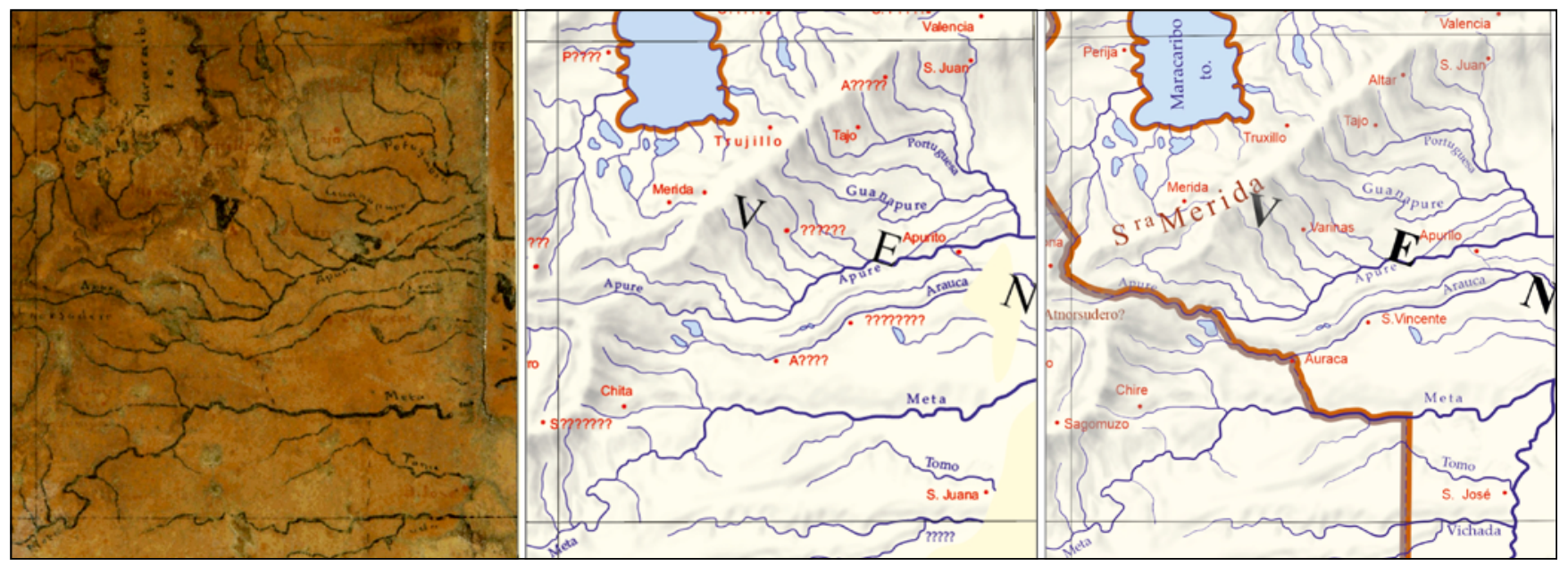

1. ábra. A földrajzi nevek digitális restaurálása (2012) és rekonstrukciója (2019)

rekonstrukció során nagyon óvatosan kell eljárni. A környezô, már restaurált térképi nevek alapján kiválasztható az a térképi forrás, amelyet Perczel is használt a névrajzának elkészítésekor. Ezt a térképet kell használni a teljesen olvashatatlan nevek helyreállításakor, figyelemmel azonban arra is, hogy Perczel törekedett a magyaros írásmódra!

Ebben az időben, a 19. század közepe táján még nem voltak elfogadott földrajzinév-írási elvek a nagyvilágban nálunk sem. Az elsố magyar nyelvú földgömb, az elsố magyar földrajzi atlaszok Debrecenben születtek a század legelején (Budai Ézsaiás és rézmetsző diákjai: 1800-1804, VGM ID 125, 126). A magyar nyelv is csak 1844-ben lett hivatalos nyelvvé hazánkban! Ha földgömbrôl beszélünk, az elôbb említetteken kívül, Nagy Károly (1840, 1855 körül, VGM ID 29, 89, 104), Schirkhuber Móric (1855 - Márton et al., 2020), valamint Hunfalvy János (1861/62-től) nevét kell sorolnunk, mint olyanokét, akik Perczel elôtt vagy vele azonos idôben magyar nyelvú glóbuszt készítettek. A gömbátmérôket vizsgálva azonban nyilvánvaló, ha Perczel ismerte is ezeket, komoly forrásmunkaként nemigen használhatta, csupán a magyar nyelvhasználatra való törekvést - mint példát - követhette, és követte is.

Korábban azt mondtuk, hogy nem voltak elfogadott névírási elvek, de még egységes névhasználatról se beszélhettünk - országon belül sem! A latin betû́s idegen nevek átvétele is gyakran egyszerúsített formában történt (egyfajta törekvésként a kiejtést közelítő „átírásra”). A nem latin betûs írást használó országok földrajzi neveinek írása/átírása további gondot okozott. Hiszen csak a Perczel-glóbusz elkészülte után, több mint tíz esztendôvel, az „A földrajzi tudományoknak Párizsban 1875-ben tartandó nemzetközi congressusára kitűzött kérdések" 88. és 89. pontja vetett fel (talán elsőként?!) ilyen kérdéseket. Nevezetesen: „88. Nem volna-e kivánatos úgy a történelmi földrajz, mint a nyelvészet haladásának érdekében, miszerint a földrajzi szónyomozások (etymologiák) egy szótárba foglaltassanak össze azon különbözố alakok (formák, melyek vagy forditják egymást kölcsönösen, vagy nem) kimutatásával, melyeket egy folyam, hegy, város vagy ország neve fölvehetett különbözô korszakokban és különféle nyelvekben? 89. Minố javitások hozhatók be a földrajzi helyesirásban? Melyek különösen a legjobb módok azon nevek latin betükkel való átiratására, melyek nem ezen alphabet szerint vannak irva?" (Földrajzi Közlemények, 1874, p. 443). Hogy itt fontos megállapodás nem született, az a III. Nemzetközi Földrajzi Kongresszus VII. osztályában (ma úgy mondanánk: szekciójában) - amelynek tematikája a „Módszertan. A földrajz tanítása és terjesztése.” volt újra felvetett kérdés mutatja. Ennek egyik megvitatásra javasolt tétele ugyanis: „2. Megkisérlése annak, hogy az összes földrajzi társaságokkal egyetértôleg a hely és személynevek egyöntetúen átirassanak, a latin betûrendszer és a külön hangok jelölésére szolgáló egyéb jegyek használásával. (Amari tanácsnok tétele.)" (Földrajzi Közlemények, 1881, p. 171).
Perczel tehát - ahogy említettük is - nem teljesen következetesen ugyan, de a kor szellemének megfelelôen törekedett a magyaros írásmódra, így a glóbuszon a név szükségszerúen eltérhet a feltételezett forrástérkép írásmódjától, de a mai magyaros írásmódtól is. Különösen igaz ez a természetföldrajzi nevek esetében, ahol az ún. földrajzi közneveket sokszor, de nem minden esetben fordította le magyarra. Néhány példát és ellenpéldát érdemes felidézni a földgömb különbözố részeirôl a mondottak bemutatására: az elsố név Perczelé, a második egy korabeli német atlasz (Universal-Handatlas, 1859) térképi neve, a harmadik a mai magyaros névhasználat (Cartographia Világatlasz, 2001).

Néhány kelet-európai név: Kanin fsz (Halbins. Kanin/Kanyin-fsz.), Novaja Semlia (Nowaja Semlja/ Novaja Zemlja), Kari Tenger (Karisches Meer/Kara-tenger), Kari ut (Karisches Strasse/Kara-szoros), Archangel (Archangel/Arhangelszk), StPETERVÁR (St. PETERSBURG/ SZANKT-PETYERBURG), Moskva (Moskau/Moszkva), Jaroslaw (Jaroslawl/Jaroszlavl), Jekaterinburg (Jekaterinburg/Jekatyerinburg). Ázsiai nevek: Bjelij (I. Bjelij/Belij-sz.), Elborrs hegység (Elburs Gb./Elburz), Persiai Öböl (Persischer Golf/Perzsaöböl), Ormus Szorasut. (Str. v. Ormus/ Hormuzi-szoros), Bab el-Mandeb ut. (Strasse Bab-el-Mandeb/Báb-elMandeb), Adeni Öböl (MB. v. Aden/ Ádeni-öböl). Néhány afrikai név: Magos Atlas (Hohes Atlas/MagasAtlasz), Nagy Atlas (Grosser Atlas/ 
Nagy-Atlasz), Sahara sivatag (Sahara/ Szahara), Also Guinea (Nied. Guinea/ Alsó-Guinea), Capföld (Kapland/ Fokföld), Cape Taun (Capstadt/Cape Town, illetve Fokváros). Végül néhány példa még az amerikai kontinensekrôl is: Barrov f. (Barrow Sp./Barrowfok), Jukon (Jukon/Yukon), C. Alfred (Prz. Alfred C./ -), Maklintok f. (C. Maclintock/-), Yellov Stone (Yellow Stone R./Yellowstone), Misisipi (Mississippi/ Mississippi), Hudson utja (Hudson's Strasse/Hudson-szoros), BUENOS AYROS (Buenos Ayros, illetve Buenos Ayres/Buenos Aires), Rio de la Plata (Rio de la Plata/La Plata), RIO JANEIRO (Rio de Janeiro/ Rio de Janeiro).

A teljesség igénye nélkül is érdemes itt megvizsgálni néhány nevet annak érdekében, hogy fényt derítsünk a névírásban alkalmazott elvekre. Általában igaznak mondható, hogy Perczel lefordítja a földrajzi közneveket: félsziget, tenger, hegység, öböl, ut/szorasut = szoros, fok stb. Az orosz neveknél azt láthatjuk, hogy ha van, magyar egzonimát használ: St Petervár, illetve a németes átírást/megnevezést követi: Archangel. Az idézett afrikai nevekból kitûnik, hogy Perczel az ún. földrajzi jellegú jelzók lefordítására is törekszik: magos, nagy, alsó stb. Ugyancsak érdekes az amerikai nevek kezelése. Itt is találkozunk németes névalakkal: Jukon (az angol Yukonnal szemben), de sajátos „magyaros kiejtést imitáló" névformákkal is: Misisipi (az „sz” hangot nem írja át!), Maklintok f.[ok]. Van azonban, ahol a fok cape marad: C. Alfred. Szinte rendszeres a „W" helyettesítése „v”-vel: Barrov f.[ok], Yelov Stone stb.

Néhány szót kell még itt ejtenünk a nem véletlenül idézett német atlaszról, az Universal-Handatlasról. Az atlasz lapjait Perczel bizonyíthatóan sok esetben használta a földgömb szerkesztésekor: elsôsorban az európai, ázsiai és az afrikai területeken. Az igen nagyszámú rajzi egyezés, egyes térképlapok esetében a névrajz szinte maradéktalan átvétele - gyakran a németes írásmód megtartásával -, mind e mellett szólnak. Egészen biztosan állítható, hogy ez az egyik alapvetô forrásmunkája volt. Természetesen lehetett ez a mú valamelyik elôző kiadása, például az 1857-es „fünfte Auflage”, vagy még korábbiak is!

\section{Az interaktív névmutató készítésének előzményei}

A Perczel-glóbusz rekonstrukciója során számos kihívással kellett szembenéznünk, mégis az egyik legfontosabb és legidôigényesebb feladat a nevek restaurálása és rekonstrukciója volt. A nevek helyreállításához hasznos segítségnek ígérkezett a glóbuszon lévő nevek feltérképezése.

\section{Az elsố változat}

Az elsô névgyújtési próbálkozásaink három alapszakos hallgató TDK-dolgozatának, illetve szakdolgozatának eredményeként 2009ben születtek, amelyek Európa, DélAmerika és Afrika településneveit foglalták magukba (Nyuli 2009, Tóth 2009, Való 2009, Tóth et al. 2009). Az így létrejött adatbázisban nemcsak a glóbuszon található nevek szerepeltek, hanem a mai neveket is összegyưjtötték a témán dolgozó hallgatók. Végül a földrajzi koordinátákat is rögzítették az adatbázisban, és KMLformátumban jelenítették meg ezeket a Google Earth programban. Ennek az adatbázisnak a szerkezete kicsit eltér a maitól (I. táblázat). Az elsố oszlopban azok a nevek vagy névrészletek szerepelnek, amelyeket a Perczel-gömbrôl egyértelmúen le tudtak olvasni, a második oszlopban a település mai neve található.

\begin{tabular}{|c|c|c|}
\hline $\begin{array}{c}\text { Leolvasott } \\
\text { név }\end{array}$ & $\begin{array}{c}\text { Valószínú } \\
\text { név }\end{array}$ & Olvasható? \\
\hline Tananarivo & Tananarivo & Igen \\
\hline M??umba & Mayumba & Nem \\
\hline Malenba? & & Nem \\
\hline \multicolumn{3}{|c|}{ 1. táblázat. Példák az adatbázis elsố }
\end{tabular}
változatából

Két évvel később ehhez a KMLfájlhoz készített egy BSc-s hallgató a szakdolgozata keretében egy adatbázist és egy webes felületet (Tokai 2011). Ezen a honlapon az egyes településnevekre lehetett keresni, és a keresôben a névre kattintva rá lehetett nagyítani a megjelenítő ablakban a kiválasztott név szúkebb környezetére a földgömbön. A virtuális gömbön az eredeti Perczel-glóbusz textúrája jelent meg (VM ID 76). A megjelenítéshez az akkoriban még futó és modernnek minôsülő, könynyen programozható Google Earth plugint használta.

\section{A névmutató második, kibóvített változata}

2012-ben a Perczel-glóbusz teljes felületére elkészült a földgömbtérkép grafikai és névrajzi restaurálása $10^{\circ}$ szélességú gömbszegmensek formájában. Ezek felhasználásával mód nyílt egy új virtuális glóbusz összeállítására (VGM ID 110). A korábbi Tokai-féle feldolgozáshoz képest jelentôsen bôvült a névanyag, célszerúnek tûnt továbbgondolni az interaktív névmutatót. Márton Mátyás Ungvári Zsuzsannát kérte fel a korábbi adatbázis településneveinek kiegészítésére, illetve a glóbuszon található összes földrajzi név adatbázisba szervezésére. E feladat megoldása azonban a program olyan bôvítését is megkívánta, amely a pontszerúen (koordinátapárral) kezelhetô településneveken túl képes a vonalas vagy felületi térképi objektumok neveinek kezelésére is.

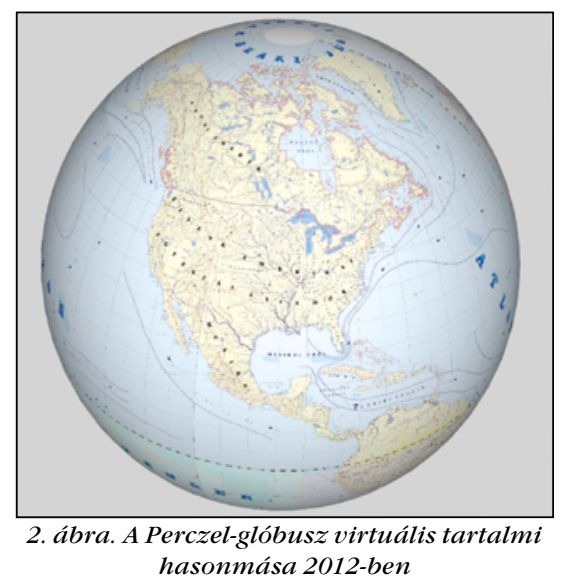

Ungvári a Tokai-féle weboldalt használta fel alapként, és bővítette ki újabb funkciókkal. Áttekintette az interaktívnévmutató-projekt szervezési és múszaki menedzselésének lehetôségeit, és a következó években a folyó munkával párhuzamosan mind hazai (Ungvári 2012), mind nemzetközi tudományos rendezvényeken (Ungvári et al. 2013, Ungvári 2014) ismertette és publikálta az elért eredményeket. A legnagyobb változást a településnevek bővülésén túl az egyéb földrajzi nevek (folyók, 
országok és hegységek stb.) megjelenése és kezelése jelentette. A névgyújtési folyamatban számos kiváló hallgató vett részt (Gulyás Zoltán, Kacsándi László, Kirisics Judit, Nemes Krisztián, Szabó Renáta, Zubán Diána Erzsébet és mások). rajzi neveket begépelni egy keresési sávban kellett, de a két névcsoport egymástól elkülönülten jelent meg két fix méretû legördülő listában. A hasonló kezdetû́ találatokat megmutatta a keresô. Emellett e fejlesztésben Ungvári bevezette a nevek kontinensek szerinti szúrését, valamint a Google Earth (GE) plugin felületét is bôvítette. Választhatóvá vált az eredeti Perczel-gömb textúrája mellett a rekonstruált raszteres réteg aktuális állapotának megtekintése is. Sôt a GE múholdképeivel is össze lehetett vetni a névrajzot. Ez egy csúszka segítségével valósult meg, amellyel a textúra átláthatósága volt állítható. Emellett a neveket tartalmazó KML-fájlok is elérhetôk voltak (3. ábra).

A településnevek felvétele az adatbázisba a település helyét jelzô vörös pont földrajzi koordinátáinak megadásával történt. A többi földrajzi név felvételéhez és kezeléséhez pedig a következô rendszer született: egy olyan keresôhálózat kialakítása történt, melynek beosztása a gömbön lévô fokhálózattal
A településneveket és az egyéb föld-

egyezik, vagyis $5 \times 5^{\circ}$-os. A hálózat sorai - az Egyenlítôtôl a sarkok felé haladva - betû́kkel (A, B, C...), az oszlopai számokkal (1-72) azonosíthatók. Az azonos betûjelzést kapott foktrapézok megkülönböztetésére az északi féltekén lévôk „N”, a délin fekvők pedig „S” kezdőbetúvel egészültek ki. Ha a név kiterjedése „kicsi”, vagyis a név egy $5 \times 5^{\circ}$-os foktrapézba esik, akkor annak keresőhálózati neve a foktrapéz neve, pl. 24SC. Ha nagyobb kiterjedésú, elnyújtott megírású a név (pl. Orosz Birodalom), akkor a név elejét és végét tartalmazó foktrapézok kódját kell elmenteni. Ezekhez a keresőhálózati nevekhez egyszerúen rendel a programkód földrajzi koordinátákat. A megjelenítố pedig az $5 \times 5^{\circ}$-os foktrapézra irányítja a képernyôkivágatot. Itt rövid böngészés után megtalálhatja a nevet a felhasználó.

Azért esett a választás erre a módszerre, mert ez hasonlít leginkább a térképek hagyományos névmutatójához. Volt egy olyan elképzelés is, hogy ez alapján könnyú lenne nyomtatni egy katalógust, amely betúrendben tartalmazza a neveket és segítségével könnyen megtalálhatók a glóbuszon, ha meg van rajta írva a keresôháló is. Másrészt ezzel a módszerrel viszonylag egyszerúen, gyorsan megadható a név felvétele az adatbázisba, kezdetben egy Excel-táblázatba. Nem kell

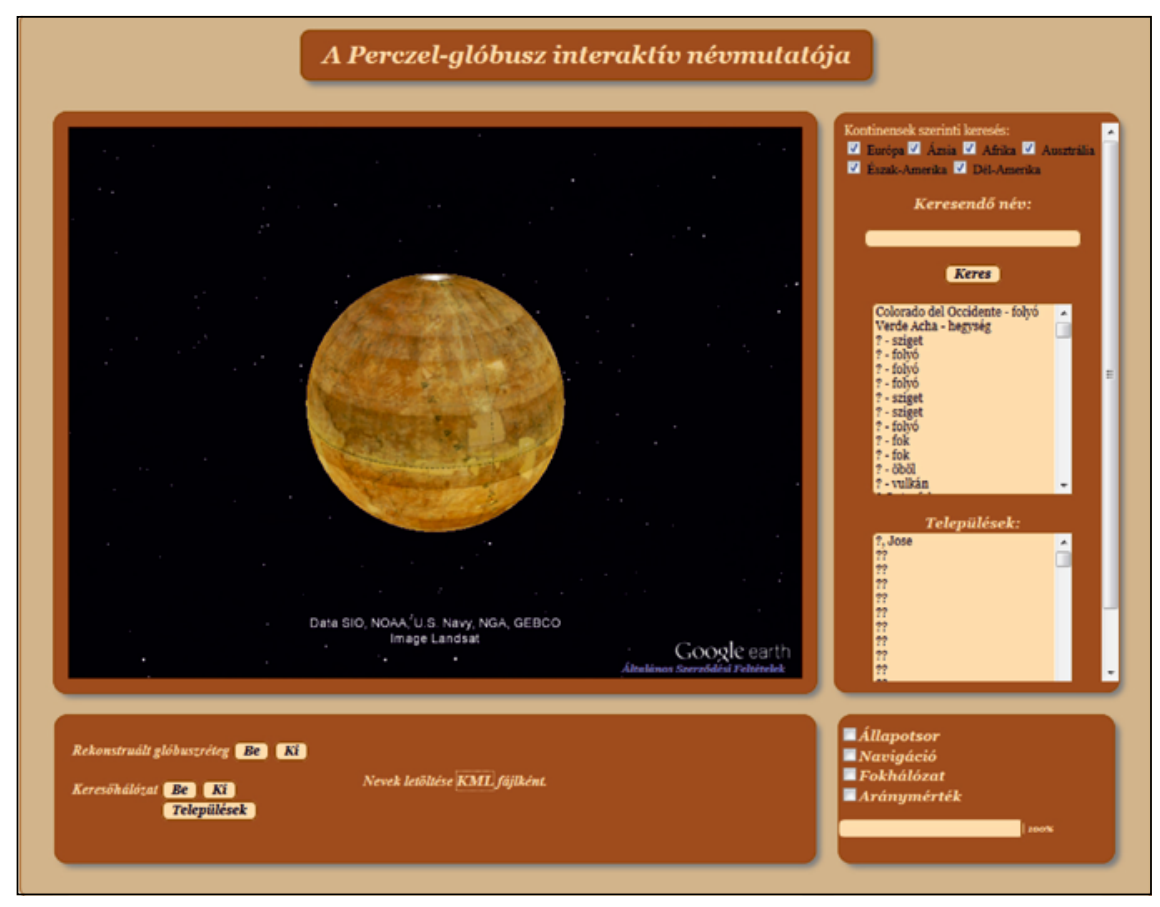

3. ábra. A névmutató kibôvített, magyar nyelvü változata 2012 után térinformatikai szoftverekben pontokat/vonalakat/felületeket felvenni az egyes elemekhez, majd azokból készíteni el az adatbázist. E módszer alkalmazása a ferrói és a greenwichi kezdőmeridián közötti átszámolásokat is egyszerúvé teszi.

A weboldal MySQL-adatbázist használt, PHP alapokon, a Google Earth megjelenító plugin alkalmazást pedig JavaScriptben írta meg Ungvári Zsuzsanna.

\section{Megszúnik a GE plugin}

Sajnos a Google Earth plugin szolgáltatást időközben - 2017 elején - leállították, így az új felhasználók nem tudták azt installálni. Ekkor egy kissé egyszerúsített megjelenítô felületet hozott létre Ungvári a Cesium JS virtuális glóbuszán, hogy a keresôhöz a hozzáférést biztosíthassuk. Ez a GE plugint „pótolta”. (Ám ezen csak az eredeti textúrát lehetett megjeleníteni, a láthatóság már nem volt állítható, és a rekonstruált glóbuszréteg, valamint a keresôhálózat is hiányzott). Az adatbázisban változás nem történt.

\section{A Perczel-projekt újraindulása és az új interaktív névmutató}

A glóbusz 2012-ben elkészült állapota után évekre leállt a Perczel-projekt. Az 2017-es Cesium JS-re való kényszerú áttérést kivéve a névmutató fejlesztése is leállt.

2018 végén megállapodás született, hogy az Archiflex Stúdió szervezésében három múvészi hasonmáspéldány készül a Perczel-glóbuszról 2019 folyamán, amelynek feltétele a 2012-ben megszakadt kartográfiai digitális restaurálás és rekonstrukció minél teljesebb körú és minél gyorsabb végrehajtása volt 2019 elsô félévében, a hasonmások készítésével párhuzamosan. A kartográfiai munkák Márton Mátyás vezetésével és tényleges részvételével, Paksi Judit közremúködésével folytak (Márton 2019), a hasonmáskészítés múvészeti vezetóje Lente Zsuzsanna okl. tárgyrestaurátor múvész volt (Lente-Kecskés 2020). A teljes projekt koordinátora Lente András építész, az Archiflex Stúdió munkatársa volt. 
A kartográfiai munka eredményeinek felhasználása módot adott egy új, restaurált és rekonstruált virtuális glóbusz összeállítására is, amely 2020-ban valósult meg (VGM ID 153).

A kartográfiai munka részeként természetesen sor került a már elkészült névanyag felülvizsgálatára és kiegészítésére, ahogy arról az elôzôekben már röviden számot adtunk.

A Perczel-glóbusz virtuális rekonstrukciója során létrejött kétszer 36 darab, $10^{\circ}$ széles, az Egyenlítôtôl a sarkokig nyúló, Cassini-Soldner-vetületú „fél” gömbkétszög. Georeferálás után ezeket négyzetes hengervetületben (meridiánban hossztartó hengervetületben) raktuk össze (Gede 2009), és ezt a térképet importáltuk GISszoftverbe (QGIS).

Ez szolgált alapul Ungvári Zsuzsanna számára a geoadatbázis felépítéséhez. Mivel rengeteg változás történt, ezért a feldolgozás a következôképpen folyt: a településnevek esetében nemcsak a megváltozott neveket kellett frissíteni, hanem sok esetben a pozíciójukat is pontosítani kellett. A többi földrajzi névnél Ungvári elvetette a korábbi keresôhálózati $5 \times 5^{\circ}$-os rendszert. A kisebb kiterjedésú neveket egy koordinátapárral, a nagyobb kiterjedésú neveket pedig vonalak menti vagy felületi kiterjedéssel mentette el az adatbázisba. Ez ugyan kissé bonyolultabbá tette az adatok feldolgozását, de pontosabb adatbázist eredményezett, amely az elemre nagyítást egyértelmúbbé teszi a felhasználó számára.

Felmerülhet a kérdés, hogy miért nem tárolta el minden földrajzi objektum koordinátáit, és a hozzá kapcsolódó nevet, és miért nem azokat jelenítette meg a webes felületen. A raszteres képek (glóbuszok textúrájának) hálózaton keresztüli letöltése a nagy felbontásuk miatt így is lassú, egy kisebb teljesítményú gépet eléggé igénybe vesz. A több mint 8700 vektoros elem egyidejú utaztatása a hálózaton összeomlasztana minden böngészőt. A Cesium JS nem múködik ennyi adattal. Alternatív megoldás lehetne pl. csak a keresett elem vektoros adatainak betöltése. Mivel azonban a raszteres textúra ott van a háttérben, és az sokkal szebb, mint amit el tudnánk érni a vektoros grafikával a Cesiumban, ezért felesleges.

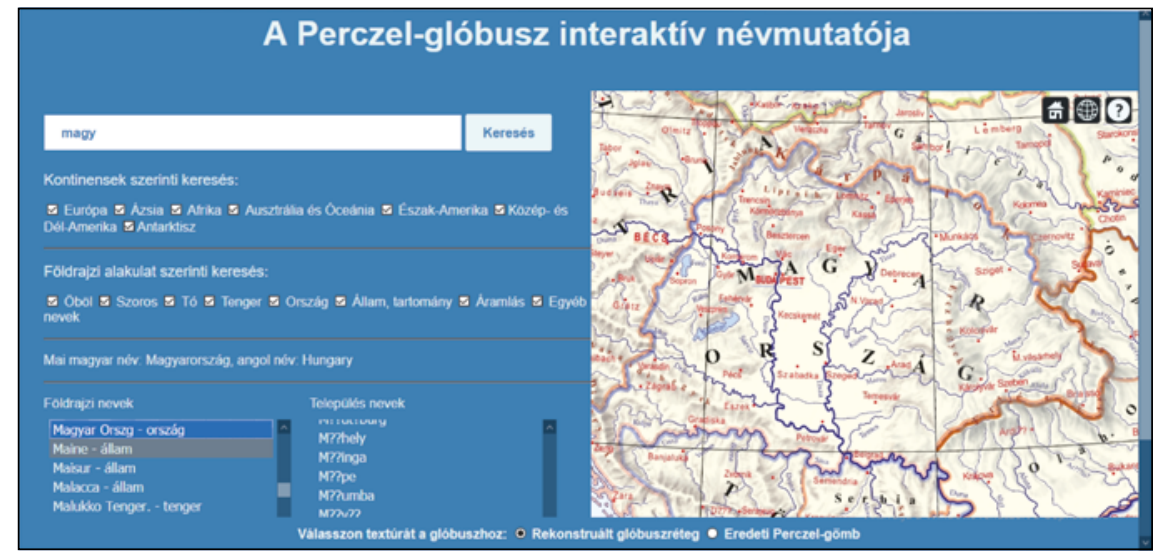

4. ábra. A megújult magyar nyelvú névmutató 2021-ben

Csak a raszteres textúra képes visszaadni a Perczel-glóbusz rajzi finomságát és szépségét.

Nemcsak az adatbázist, de magát a honlapot is fejlesztettük. Bôvültek a szûrési lehetôségek: a kontinensek szerinti szúkítés mellett lehetôség van a földrajzi nevek típusa szerinti szúrésre is. A településnevek és az egyéb földrajzi nevek két listába történố elkülönítése megmaradt, a nevek könnyebb értelmezhetôsége miatt. Háttérként az eredeti és a rekonstruált glóbusztextúra tölthetô be. A honlap technológiai alapjai nem változtak az utolsó frissítés óta. A fentiek mellett a projekt magyar és angol nyelvú rövid leírása is olvasható a weboldalon.

\section{Az interaktív névmutató elérhetósége}

Az interaktív névmutató a következô direkt linkrốl indítható: http:// terkeptar.elte.hu/vgm/perczel. Ha az érdeklődők először a Virtuális Glóbuszok Múzeumát keresik fel (http://terkeptar.elte.hu/vgm vagy http://vgm.elte.hu), oda belépve a „Kapcsolódó projektek”-ból kiválasztható a „Perczel-glóbusz interaktív névmutatója" (4. ábra).

\section{Sokatmondó statisztika}

Hogy képet alkothassanak a projekt nagyságáról, a nevek azonosításának, írásmódjuk pontosításának nehézségérôl, néhány névcsoportra vonatkozó statisztikai adat bemutatása segít az olvasóknak. Perczel földgömbjén összesen 8874 (eddig felderített) név található. A glóbusz átmérôje 127,5cm, méretaránya 1 : 10000 000. A 2. táblázatban összegezzük a végsố adatbázisban szereplố névtípusok adatait.

Az eredmény nem véletlen. A vörös színnel írt településnevek csoportjában találjuk a legtöbb olvashatatlan nevet. Ennek oka a földgömb 1970es években végzett fizikai restaurálásának nem körültekintố végrehajtása, amelynek során a „védô” lakkrétegnek kiválasztott vegyi anyagban bekövetkezô elszínezôdést (egyre sötétebb barnába hajló sárgulást) nem vették figyelembe. Ez az eltelt idôk folyamán egyre inkább „elfedte”, összemosta a színeket, sốt úgy tûnik, hogy a vörös szín festékanyagát részben magába oldotta. Bár a folyónevek betûmérete majdnem megegyezik a településekével, sötétkék színú megírásuk miatt azonban sokkal kisebb az olvashatatlan folyónevek aránya.

A szerzốk összeszámolták azokat a teljesen olvashatatlan, így nem azonosított településneveket is, amelyeket csak három kérdőjel jelölt: ez 144 tételt jelentett (az összes településnév 3,4\%-át). Az összes többi név legalább egy betût tartalmazott, amely elősegítette az azonosításukat.

Az adatbázis változásainak szemléltetésére a korábbi (2012-es) verzióval szemben, a szerzôk néhány összehasonlítást tettek. Az adatbázis elốzố változatában 7302 név szerepelt $(3403$ településnév és 3899 egyéb földrajzi név). Ez a szám 1572-vel kevesebb, mint a végsô. Ez a különbség két forrásból származik: új nevek jöttek a kiegészített területekrốl, és azokról a területekrôl, amelyeket az elôzố változatban nem dolgoztak fel (pl. Kis-Ázsia, Ausztrália egyes részei). 


\begin{tabular}{|l|l|l|l|}
\hline A név típusa & $\mathbf{1}$ & $\mathbf{2}$ & $\mathbf{3}$ \\
\hline Település & 4258 & 1408 & $33,1 \%$ \\
Sziget vagy szigetcsoport & 1076 & 23 & $2,1 \%$ \\
Zátony & 24 & 0 & $0,0 \%$ \\
Folyó & 1727 & 89 & $5,2 \%$ \\
Tó (mocsár) & 219 & 1 & $0,5 \%$ \\
Óceán és tenger & 44 & 0 & $0,0 \%$ \\
Öböl & 183 & 3 & $1,6 \%$ \\
Földfok & 339 & 13 & $3,8 \%$ \\
Hegy & 269 & 27 & $10,0 \%$ \\
Vulkán & 110 & 11 & $10,0 \%$ \\
Tengerszoros, átjáró & 69 & 0 & $0,0 \%$ \\
Tengeráramlás & 27 & 1 & $3,7 \%$ \\
Nép & 45 & 1 & $2,2 \%$ \\
Igazgatási név (ország, állam, tartomány) & 232 & 6 & $2,6 \%$ \\
Egyéb terület (pl. sivatag) & 226 & 15 & $6,6 \%$ \\
Pontszerú képzódmény & 20 & 4 & $20,0 \%$ \\
Fokhálózati név & 6 & 0 & $0,0 \%$ \\
\hline Összesen & 8874 & 1602 & $18,1 \%$ \\
\hline
\end{tabular}

2. táblázat. 1: Az egyes kategóriákba sorolható nevek száma.

2: Azon nevek száma a kategórián belül, amelyek legalább egy kérdôjelet tartalmaznak. 3: A 2-es oszlopban található nevek aránya az adott névcsoporton belül

A korábbi adatbázisban a legalább egy kérdôjelet tartalmazó nevek száma 2580 volt, ebból 2322 településnév (ami 68\%-a a 3403 településeknek!) és 258 egyéb földrajzi név volt. Ha összehasonlítjuk ezt a legutóbbi értékkel (33\%), láthatjuk, hogy a 2019. es feldolgozás során a szerzốk sokkal magasabb arányt értek el a városnevek azonosításában. Minden névcsoportot figyelembe véve összesen 3252 nevet egészítettek ki vagy cseréltek le a földgömbön.

\section{Kitekintés}

A bemutatott új interaktív névmutató földgömb-vizualizációkon alapul, de ez nem egyedülálló a webkartográfiában, hiszen például a GEBCO is Cesium JS-könyvtárat használ a tengerfenékdomborzati képzôdmények mai elnevezéseit tartalmazó névmutatójához (GEBCO website 2021).

\section{Összefoglalás}

Jelen dolgozatban a szerzôk felvázolták a Perczel-projekthez szorosan kapcsolódó, a földgömb új interaktív névmutatója elkészítésének projektjét, megmutatták annak kihívásait és a létrehozott névmutató jellegzetességeit. A hallgatói közremúködéssel a korábbi években összegyújtött földrajzinév-adatbázis teljesen megújult: bôvítése, átdolgozása megtörtént, amelynek során számos névjavítást hajtottak végre, új nevekkel gazdagították, új szűrési lehetôségekkel bôvítették a keresést. Emellett megújult a projekt weboldala is.

\section{Irodalom}

Ambrus-Fallenbüchl Zoltán 1963 Magyarország legnagyobb földgömbje száz éves. Geodézia és Kartográfia, 15. évfolyam, 1. szám, pp. 61-62.

Cartographia Világatlasz 2001. Cartographia Világatlasz. Cartographia Kft., Budapest

Földrajzi Közlemények 1874. A földrajzi tudományoknak Párizsban 1875-ben tartandó nemzetközi congressusára kitűzött kérdések. Földrajzi Közlemények, 2. kötet, Budapest, pp. 448-458.

Földrajzi Közlemények 1881. A III-dik nemzetközi földrajzi congressus tételei. Földrajzi Közlemények, 9. kötet, Budapest, pp. 164-171.

GEBCO website (2021): https://www.gebco.net/

Gede, Mátyás 2009. The Projection Aspects of Digitising Globes. In Hunt E. et al. (ed.) 2009. Proceedings of the XXIV. International Cartographic Conference. Santiago, Chile, Paper 10/1.

Lente Zsuzsanna - Kecskés Barbara 2020. A Perczel földgömb rekonstrukciója. Geodézia és Kartográfia, 72. évfolyam, 5. szám, pp. 29-31.

Márton Mátyás 2019. A Perczel-glóbusz újraalkotásának legújabb fázisa. Geodézia és Kartográfia, 71. évfolyam, 1. szám, pp. 18-27.

Márton Mátyás - Toronyi Bence 2020. Az elsô magyar nyelvú Felkl-glóbusz megalkotói
Geodézia és Kartográfia, 72. évfolyam, 4. szám, pp. 20-28.;

DOI: $10.30921 / \mathrm{GK} .72 .2020 .4 .3$

Nyuli Éva 2009. Európa településeinek térinformatikai adatbázisa a Perczel gömb alapján. BSc-szakdolgozat, ELTE Térképtudományi és Geoinformatikai Tanszék, Budapest

Tokai Tibor 2011. Webes interaktív névmutató készítése virtuális glóbuszokon. BScszakdolgozat, ELTE Térképtudományi és Geoinformatikai Tanszék, Budapest

Tóth Bettina 2009. Dél-Amerika településneveinek geoadatbázisa a Perczel-glóbusz alapján. BSc szakdolgozat, ELTE Térképtudományi és Geoinformatikai Tanszék, Budapest, 2009.

Tóth Bettina - Való Adrienn 2009. Geoinformatika a kulturálisérték-mentés szolgálatában (Régi térképek földrajzi neveinek adatbázis-építése). OTDK dolgozat, ELTE Térképtudományi és Geoinformatikai Tanszék, Budapest

Ungvári, Zsuzsanna 2012. Névrajzi keresôrendszer kialakítása a Perczel-glóbuszokhoz. Elốadás, Budapest, http://lazarus.elte.hu/ hun/buszke/2012-perczel/perczel.htm

Ungvári, Zsuzsanna - Tokai Tibor 2013. The interactive gazetteer of a 150-year-oldglobe. In Manfred, F. - Buchroithner (ed.) 2013. Proceedings of the 26th International Cartographic Conference. Dresden, Germany: International Cartographic Association, 2013 pp. 721-722.

Ungvári, Zsuzsanna 2014. A Method to Create Interactive Gazetteer to Old Globes. In Livieratos, E. - Pazarli, M. (eds.) 9th International Workshop on Digital Approaches to Cartographic Heritage. pp. 280-287.

Universal-Handatlas 1859.Heinrich Berghaus, Glogau

Való Adrien 2009. Afrika tepülésneveinek geoadatbázisa a Perczel-glóbusz alapján. BSc-szakdolgozat, ELTE Térképtudományi és Geoinformatikai Tanszék, Budapest

Virtuális Glóbuszok Múzeuma (2007-): VGM ID $29,89,104,110,125,126,153$. ELTE Térképtudományi és Geoinformatikai Intézet, Budapest

http://terkeptar.elte.hu/vgm vagy http://vgm.elte.hu

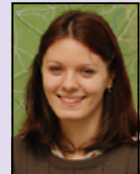

Dr. Ungvári Zsuzsanna egyetemi adjunktus

ELTE Térképtudományi és Geoinformatikai Intézet ungvarizs@map.elte.hu

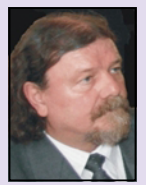

Dr. Márton Mátyás professor emeritus

ELTE Térképtudományi és Geoinformatikai Intézet matyi@map.elte.hu 